\title{
PTGS2 Gene
}

National Cancer Institute

\section{Source}

National Cancer Institute. PT GS2 Gene. NCI Thesaurus. Code C26598.

This gene is involved in mitogenesis, inflammation and angiogenesis. 